PSIKOPEDAGOGIA, Vol. 1, No. 2, Desember 2012

ISSN: 2301-6167

\title{
PERBEDAAN EMOTIONAL FOCUSED COPING MAHASISWA KOST DENGAN MAHASISWA YANG TINGGAL DENGAN ORANG TUA PADA MAHASISWA JURUSAN BIMBINGAN DAN KONSELING FAKULTAS KEGURUAN DAN ILMU PENDIDIKAN UNIVERSITAS AHMAD DAHLAN YOGYAKARTA
}

\author{
DIFFERENCES EMOTIONAL FOCUSED COPING BETWEEN STUDENTS STAY \\ INBOURDING HOUSE WITH STUDENT LIVING WITH PARENTS ON STUDENT \\ GUIDANCE AND COUNSELING DEPARTMENT FACULTY TEACHER TRAINING \\ AND EDUCATION UNIVERSITY OF AHMAD DAHLAN YOGYAKARTA
}

\author{
Erni Hestiningrum \\ Universitas Ahmad Dahlan
}

\begin{abstract}
Abstrak
Penelitian dilatarbelakangi oleh banyaknya mahasiswa yang berasal dari luar daerah terpaksa harus tinggal di tempat kost, artinya para mahasiswa kost ini harus mampu sendiri dalam menghadapi segala hal yang berkaitan dengan kehidupannya baik dalam rangka pemenuhan kebutuhan biologis seperti makan, minum, berteduh maupun kebutuhan psikologisnya seperti penyesuaian diri dengan lingkungan kost, lingkungan kampus serta lingkungan pergaulan yang luas. Penelitian ini bertujuan untuk mengetahui apakah emotional focusedcopingmahasiswa kost lebih tinggi daripada emotional focusedcoping mahasiswa yang tinggal dengan orang tua pada mahasiswa jurusan Bimbingan dan Konseling.Subyek dalam penelitain ini adalah mahasiswa Jurusan Bimbingan dan Konseling tahun akademik 2008/2009 yang berjumlah 309 mahasiswa. Metode pengambilan data menggunakan skala. Skala yang digunakan dalam penelitian adalah Skala Emotion-Focused Coping sebanyak 30 item. Analisis data yang digunakan dengan Uji-t. Hasil penelitian Emotional focused coping pada mahasiswa Bimbingan Konseling FKIP UAD yang tinggal di kost lebih tinggi dari pada emotional focused coping mahasiswa yang tinggal di rumah orang tua.
\end{abstract}

Kata kunci:emotional focused coping

\begin{abstract}
The research is motivated by the many students who come from outside the region are forced to live in a boarding house, meaning that the students boarding should be able to own in dealing with all matters relating to life both in order to meet the biological needs such as food, drink, shelter and psychological needs such adjustments themselves with boarding environment, campus environment and the broad milieu. This study aims to determine whether the emotional focused coping boarding students is higher than the emotional focused coping students living with parents on student majoring in guidance and counseling. The subjects of the research is a student in the Department of Guidance and Counseling academic year 2008/2009 totaling 309 students. The data collection method using a scale. The scale used in the study are Emotion-Focused Coping Scale 30 items. Analysis of the data used by the t-test. Results of research on student focused coping Emotional Counseling FKIP UAD living in the boarding house is higher than the emotional focused coping students who stay at home parents.
\end{abstract}

Keywords:emotional focused coping

\section{PENDAHULUAN}

Mahasiswa berada dalam taraf perkembangan tertentu, satu masa transisi ke kedewasaan.Ia sedang mencari identitas diri

sendiri dan sedang mencari satu gaya hidup sendiri. Dengan eksperimen sesuai kemampuannya dan kesanggupannya, dan sebagai mahasiswa harus menerapkan hal-hal 
baru yang belum pernah dilakukan. Mahasiswa yang berasal dari berbagai latar belakang ekonomi, sosial, kebudayaan,agama dan pendidikan tersebut masuk dalam satu wadah pengelolaan. Bagi mahasiswa yang berasal dari luar daerah dimana Perguruan Tinggi tersebut berada akan merasakan sekali perubahan-perubahan yang harus dilakukan tersebut, sehingga hal itu dapat menimbulkan masalah dan tentu saja juga mempengaruhi cara-cara dalam penyelesaian masalah tersebut.

Banyak perubahan yang dialami mahasiswa baik perubahan biologis maupun psikologis seperti perubahan status di dalam masyarakat, munculnya dorongan seksual, penyesuaian diri dalam cara belajar, jauh dari keluarga, penyesuaian dalam cara bergaul karena perubahan status dari anak sekolah menjadi seorang mahasiswa, dan hal tersebut akan mempangaruhi keadaan emosinya.

Sumber lain munculnya permasalahan pada mahasiswa adalah dari teman sebaya. Sebagai contohya adalah permasalahan bulliying yang kerap terjadi di berbagai setting kehidupan. Seperti di sekolah/kampus, di rumah, di pondok pesantren, di tempat penitipan anak, di tempat kursus/les, di kantor, di area tempat bermain, dan lain sebagainya. Menurut Sucipto (2012) bullying dapat berbentuk fisik, seperti pukulan, tendangan, tamparan, dorongan, serta serangan fisik lainnya. Secara non fisik, bullying dapat dilakukan secar verbal dan nonverbal, ejekan, panggilan dengan sebutan tertentu, ancaman, penyebaran gosip, perkataan yang mempermalukan tergolong aksi verbal. Ekspresi wajah yang tidak menyenangkan dan bahasa tubuh yang mengancam merupakan aksi nonverbal yang dilakukan secara langsung. Sedangkan pengabaian, penyingkiran dari kelompok, serta pengiriman pesan tertulis yang bernada mengganggu, dan merebut pacar, termasuk aksi nonverbal secara tidak langsung.

Adanya masalah-masalah yang begitu kompleks yang terjadi pada mahasiswa, ada sebagian yang berhasil mengatasi masalahnya, namun ada juga yang mengalami kegagalan dalam menyelesaikan masalah yang dihadapinya. Sarafino (1997) mendefinisikan copingsebagai suatu proses dimana individu mencoba mengatur tuntutan-tuntutan, baik tuntutan yang berasal dari individu maupun tuntutan yang berasal dari lingkungan dengan menggunakan sumber yang dimiliki individu guna mengatasi situasi yang stressfull. Lazarus (dalam Smet, 1994) mengatakan metode coping dibagi menjadi dua model, yaitu (1) coping yang berfokus pada permasalahan disebut problem-focused coping dan (2) coping yang berfokus pada emosi disebut emotional ffocusedcoping. Penggunaan problem-focused coping (PFC) apabila penyelesaian sesuai pokok permasalahan. dan penggunaan emotional focused coping (EFC) apabila penyelesaian dengan emosi. Menurut Mappiare (1982) bahwa cara pengatasan masalah yang dialami mahasiswa yang dalam masa transisi , sering digunakan adalah dengan cara-cara emosional. Pada masa transisi , mahasiswa cenderung menghadapi masalah dengan cara emosional karena masa tersebut penuh dengan badai dan topan yaitu perasaan yang penuh gejolak dan peka terhadap rangsang negatif, remaja menggunakan cara ini untuk meminimalkan atau menghilangkan tekanan atau stres. Silver dan Wortman (Folkman, 1984) menyatakan individu yang dapat mencari segi-segi positif dari situasi negatif akan memiliki tingkat stress yang lebih rendah dibandingkan individu yang menggunakanemotional focusedcoping. Menurut Folkman \& Lazarus (Davison dkk, 2004)emotional focusedcoping merupakan perilaku menghadapi masalah yang berorientasi pada emosi dimana individu berusaha menghadapi masalah secara tidak langsung dan untuk mengurangi berbagai reaksi emosional negatif terhadap stressor, dengan mengalihkan perhatian dari masalah, melakukan relaksasi, ataumencari rasa nyaman dari orang lain. Sebenarnya pemakaian emotional focused coping cenderung membawa individu pada keadaan insecure, mempunyai kekhawatiran berlebihan, merasa bersalah dan murung, karena teknik emotional focused coping menghadapi masalah tidak secara langsung dan lebih mengarah pada usaha menyeimbangkan afeksi. Emotional focused coping dapat dilihat jika individu sedang mengalami suatu permasalahan. Mahasiswa yang menggunakan emotional focused coping cenderung melakukan pendekatan secara emotional yang berupa mencari dukungan sosial karena adanya rasa solidaritas dari kelompok sebaya, penolakan terhadap masalah yang ditandai dengan perilaku merokok dan pemekaian narkoba, atau berusaha menarik diri. 
Faktor-faktor yang dapat mempengaruhi emotional focused coping yaitu kondisi internal berupa persepsi terhadap stimulus yang terkait dengan kesadaran diri individu, proses belajar dan pengalaman dan kondisi eksternal berupa situasi lingkungan dan dukungan sosial masyarakat yang tercipta bila individu memiliki kemampuan kontrol diri, empati serta kecakapan sosial. Pengalaman yang telah diterima dari lingkungan dapat mempengaruhi perilaku seseorang.

\section{KAJIANLITERATUR}

Sarafino (1997) menyatakan emotional focused coping merupakan pengaturan respon emosional dari situasi yang penuh stress. Oleh Silver dan Wortman (Folkman, 1984) emotional focused coping sering digunakan individu untuk mencari aspek-aspek positif dari penilaian situasi permasalahan yang dinilai mengancam atau mencari aspek-aspek positif dari kegagalan-kegagalan individu dalam menghadapi masalah. Individu yang dapat mencari segi-segi positif dari situasi negatif akan memiliki tingkat stress yang lebih rendah dibandingkan individu yang tidak menggunakan emotional focused coping tersebut. Emotional focused coping ini mempunyai efek yang bersifat sementara dalam arti yang sesungguhnya yang belum terselesaikan, tetapi bisa menjadi efektif untuk mengurangi tekanan ketika situasi permasalahan telah dinilai negatif oleh individu.

Faktor-Faktor yang Mempengaruhi Emotional Focused CopingMenurut Sarafino (1997) terdapat banyak faktor yang mempengaruhipenggunaan perilaku emotional focused coping oleh individu dalam menghadapi masalah, antara lain kondisi individu bersangkutan dalam bentuk kemampuan mempersepsi stimulasi yang terkait dengan pengalaman. Pengaruh lingkungan, berupa dukungan sosial dan situasi lingkungannya berpengaruh terhadap penggunaan emotional focused coping oleh remaja.

Berdasarkan Aldwin dan Revenson (1987) strategi dalam emotional focused coping dibagi menjadi sebagai berikut: (1) Escapism (pelarian dari masalah) Individu menghindari masalah dengan cara membayangkan seandainya ia berada dalam situasi lain yang menyenangkan. Individu menghindari masalah dengan makan, tidur berlebihan, merokok atau minum-minuman. (2) Minimization (pengurangan beban masalah) Individu membuat masalah menjadi selingan mungkin dan menganggap masalahnya seolah-olah tidak ada.(3) Self blame (penyalahan diri sendiriIndividu cenderung menyalahkan dan menghukum diri sendiri serta menyesali apa yang terjadi.

\section{METODE PENELITIAN}

Subyek dalam penelitain ini adalah mahasiswa Jurusan Bimbingan dan Konseling semester tahun akademik 2008/2009 yang berjumlah 309 mahasiswa.

Metode pengambilan data menggunakan skala. Skala digunakan dalam penelitian adalah Skala Emotion-Focused Coping sebanyak 30 item. Analisis data yang digunakan dengan Uji-t.

\section{HASIL PENELITIAN DAN PEMBAHASAN}

Emotional Focused Coping untuk faktor escapism (pelarian dari masalah) mahasiswa kost tidak lebih tinggi dibandingkan Emotional Focused Coping untuk faktor escapism (pelarian dari masalah) mahasiswa yang tinggal di rumah orang tua pada mahasiswa Jurusan Bimbingan Konseling FKIP UAD tahun akademik 2008/2009. Hasil ini menunjukkan bahwa escapism (pelarian dari masalah), yaitu individu menghindari masalah dengan cara membayangkan seandainya ia berada dalam situasi lain yang menyenangkan; dengan: makan, tidur berlebihan, merokok atau minum-minuman; baik pada mahasiswa kost maupun mahasiswa yang tinggal dengan orangtua tidak menunjukkan adanya perbedaan yang signifikan.

Emotional Focused Coping untuk faktor minimization (pengurangan beban masalah) mahasiswa kost lebih tinggi daripada Emotional Focused Coping untuk faktor minimization (pengurangan beban masalah) mahasiswa yang tinggal di rumah orang tua pada mahasiswa Jurusan Bimbingan Konseling FKIP UAD tahun akademik 2008/2009. Minimization (pengurangan beban masalah), yaitu individu membuat masalah menjadi seringan mungkin dan menganggap masalahnya seolah-olah tidak ada, pada 
mahasiswa yang tinggal di kost lebih tinggi dibandingkan dengan mahasiswa yang tinggal di rumah orang tua

Emotional Focused Coping untuk faktor self blame (penyalahan diri sendiri) mahasiswa kost lebih tinggi daripada Emotional Focused Coping untuk faktor self blame (penyalahan diri sendiri) mahasiswa yang tinggal di rumah orang tua mahasiswa Jurusan Bimbingan Konseling FKIP UAD tahun akademik 2008/2009. Self-blame (penyalahan diri sendiri), yaitu: individu cenderung menyalahkan dan menghukum diri sendiri serta menyesali apa yang terjadi pada mahasiswa yang tinggal di kost lebih tinggi dibandingkan dengan mahasiswa yang tinggal di rumah orangtua.

\section{KESIMPULAN}

Emotion-focused coping pada mahasiswa kost lebih tinggi dibandingkan dengan Emotion-focused coping mahasiswa yang tinggal di rumah orang tua. pada mahasiswa Jurusan Bimbingan Konseling FKIP UAD tahun akademik 2008/2009

Perbedaan pada masing-masing faktor emotion-focused coping, sebagai berikut:

a. Emotion-focused coping untuk faktor escapism (pelarian dari masalah) yang ada pada mahasiswa kost tidak lebih tinggi Emotion-focused coping untuk faktor escapism (pelarian dari masalah) mahasiswa yang tinggal di rumah orang tua pada mahasiswa Jurusan Bimbingan Konseling FKIP UAD tahun akademik 2008/2009.

b. Emotion-focused coping untuk faktorminimization (pengurangan beban masalah) mahasiswa kost lebih tinggi daripada Emotion-focused coping untuk faktorminimization (pengurangan beban masalah ) mahasiswa yang tinggal di rumah orang tua pada mahasiswa Jurusan Bimbingan Konseling FKIP UAD tahun akademik 2008/2009.

c. Emotion-focused coping untuk faktorself blame (penyalahan diri sendiri) mahasiswa kost lebih tinggi daripada Emotion-focused coping untuk faktorself blame (penyalahan diri sendiri) mahasiswa yang tinggal di rumah orang tua pada mahasiswa Jurusan Bimbingan Konseling FKIP UAD tahun akademik 2008/2009.

\section{REFERENSI}

Aldwin, C.M \&Revenson, T. A. 1987. Does Coping Help ? A Reexamination of The Relation Between Coping and Mental Health. Journal of Personality and Social Psychology.53: 337 348.

Arikunto, Suharsimi, 2002, ProsedurPenelitian, Jakarta, PenerbitRinekaCipta.

Davison dkk. 2006. Psikologi Abnormal. PengalihBahasa: Noermalasari. Jakarta: Raja GrafindoPersada.

Gunarsa, S.D. 1990.

PsikologiPerkembangan. Jakarta: P.T. Bpk. GunungMulia.

Goleman, D. 2005. KecerdasanEmosi. PengalihBahasa: Hermaya. Jakarta: Gramedia

Hadi, S. 2002. Metodologi Research Jilid 2. Yogyakarta : Andi

Mappiare, A. 1982. Psikologi Remaja. Surabaya: Usaha Nasional.

Sarafino, P.E. 1997. Health Psychology.New York: John Willey and Sons.

Sarafino, P.E. 1998. Health Psychology.New York: John Willey and Sons.

SoewondoSoesmalyah, Bimbingan dan Konseling Pengertian dan Peranannya dalam Pembinaan Mahasiswa, 2001, Jakarta, Direktorat Jendral Pendidikan Tinggi.

Sucipto. (2012). Bullying dan Upaya Meminimalisasikannya. Psikopedagogia Jurnal Bimbingan dan Konseling, 1(1): 14-22 